2014, volume 3, issue 1

Kopyściański T., Rólczyński T. (2014). Application of statistical methods in the diagnosis of environmental conditions of development of Lower Silesian voivodship in years 2006-2012. Copernican Journal of Finance \& Accounting, 3(1), 97-108. http://dx.doi.org/10.12775/CJFA.2014.008

TOMASZ KOPYŚCIAŃSKI*

Institute of Finance and Accounting, Wroclaw School of Banking

TOMASz RólCZYŃSKI**

Institute of Economy, Wroclaw School of Banking

\title{
APPLICATION OF STATISTICAL METHODS IN THE DIAGNOSIS OF ENVIRONMENTAL CONDITIONS OF DEVELOPMENT OF LOWER SILESIAN VOIVODSHIP IN YEARS 2006-2012
}

Keywords: environmental conditions of regional development, the method of standardised sums, Ward's method.

\section{J E L Classification: 044.}

Abstract: The issue addressed in the article focuses on disparities occuring within a region in terms of environmental conditions of development. The article is mainly an attempt to adapt statistical methods for the purpose of monitoring environmental conditions. Within this scope, the method of standardised sums and Ward's method have been applied. The research results pertaining to Lower Silesian Voivodship suggest that the observed disparities between the best and the worst areas in terms of the quality of natural environment are becoming more deeply embedded. In this respect, zgorzelecki county and the cities of Wrocław and Legnica can be distinguished as particularly problematic, which is crucially affected by the structure and sorts of economic activities conducted within the mentioned areas.

Date of submission: February 27, 2014; date of acceptance: March 23, 2014.

* Contact information: wouden@interia.pl, Institute of Finance and Accounting, Wroclaw School of Banking.

** Contact information: tomasz_rolczynski@o2.pl, Institute of Economy, Wroclaw School of Banking. 


\title{
ZASTOSOWANIE METOD STATYSTYCZNYCH W DIAGNOZIE ŚRODOWISKOWYCH UWARUNKOWAŃ ROZWOJU WOJEWÓDZTWA DOLNOŚLĄSKIEGO W LATACH 2006-2012
}

Słowa kluczowe: uwarunkowania środowiskowe rozwoju regionu, metoda sum standaryzowanych, metoda Warda.

Klasyfikacja J E L: 044.

\begin{abstract}
Abstrakt: Problematyka poruszana w ramach artykułu koncentruje się wokół kwestii zróżnicowania środowiskowych uwarunkowań rozwoju występujących wewnątrz regionu. Artykuł w głównej mierze stanowi próbę adaptacji metod statystycznych dla potrzeb monitorowania uwarunkowań środowiskowych. Wykorzystano w tym zakresie metodę sum standaryzowanych i metodę Warda. Wyniki przeprowadzonych badań w obrębie województwa dolnośląskiego wskazują na silne utrwalenie zaobserwowanych dysproporcji między obszarami najlepszymi a najgorszymi pod względem jakości środowiska przyrodniczego. Szczególnie negatywnie na tym tle wyróżniają się powiat zgorzelecki, oraz miasta Wrocław i Legnica, na co kluczowy wpływ ma struktura i rodzaje działalności gospodarczej prowadzonej w ramach wymienionych obszarów.
\end{abstract}

\section{IIIINTRODUTION}

The issue concerning different development rates of Poland's individual regions, which has extensively been delineated in the literature on the subject, is a deeply rooted phenomenon caused by a series of factors resulting, among others, from location attractiveness, economic potential, level of human capital and access to technical and social infrastructure as well as to public services. A particular aspect within the studied issue is the question of the environmental conditions considered, next to social and economic aspects, one of the main determinants of the development at a regional level.

The objective of the article is to analyze disparities in the environmental conditions of development within the region, taking into account the disparities occuring in individual counites. In particular, the article is an attempt to adapt statistical methods for the purpose of monitoring the environmental conditions. Therefore, on the basis of theoretical consideration, the analysis has been conducted applying selected statistical tools and focusing on comparing the situtations of Lower Silesian counties based on the data pertaining to years 2006-2012.

Applying the research to the category of region requires that the semantic content of the applied term is defined more precisely. Science disciplines and regional practices most frequently refer to the territorial and administrative division of the country. From the $1^{\text {st }}$ of January 1999, after the administrative 
reform, there has been a three-tier administrative division in force in Poland, comprising the following: communes, counties and voivodships. Putting it very simply, each of these tiers may be considered a set of a homogenous class of regions. However, in the practice of self-governments, it is assumed that the term region refers to voivodships, whereas communes and counties constitute local units. Moreover, it is acknowledged that the regional policy is run by the state in relation to all regions-voivodships (the so called interregional policy) and each voivodship runs its policy in relation to its territory (the so called intraregional policy) (Szewczuk 2011, 18). Poland's territorial embedding of the regions within the system of the sixteen voivodships also follows NUTS2 level, in accordance with the classification of territorial units for statistical purposes operating in the EU countries, which has been established to collect, prepare and disseminate comparable data for specific regional statistics within the EU territory.

The issue of disparities in the development at a regional level has in the past been the subject of many analyses on the basis of which a series of theories and concepts have been developed. Within these, a few leading research streams may be suggested comprising the location theory and regional development theory which focus on explicating the causes of disparities in the level of socio-economic development (Stackelberg, Hahne 1998, 30). A significant research stream within this scope continues to be the theory of sustainable development which has retained its popularity in the literature on the subject (Fujita 2001; Fiedor 2002; Borys 2005) and is still present in the legislation in force (most notably in Art. 5 of the Constitution of the Republic of Poland). This concept assumes that the socio-economic development should be harmonized with the natural environment in order to ensure fundamental needs of individual communities or citizens not only of this generation but also of the future ones. This means that when dealing with the development process, it is necessary to consider, in balanced proportions, three basic components:

- the economic one, assuming the need to strive for economic growth which provides real increase of prosperity and well-being,

- the social one which amounts to satisfying human needs, thereby ensuring equal opportunities of development,

- the environmental one focusing on rationally exploiting natural resources.

Preserving and protecting the environment thus ensuring its improvement is a very important objective constituting part of the Lisbon and Gothenburg strategies of the European Community. Inter-generational equity demands the preservation of the environment in such a state as to allow future generations to 
use it. In the European Union a new view has emerged that the environment can provide real economic benefits, offering new opportunities as well as stimulating economic growth in various directions. In this respect, a positive example is set by the Scandinavian countries which have been incorporating the environment in order to stimulate the economy. The example set by such countries as Sweden, Denmark, Finland demonstrates how economic objective can be achieved together with the ecological one. For many years now, these countries have invariably occupied leading positions in competition rankings. Using the environment in the regional economy has above all the following goals:

- increasing competitiveness through reducing costs for business by the more efficient use of resources;

- increasing production efficiency through the development of the sectors of the economy which contribute to the benefits resulting from the economic and environmental integration.

Thus, long term shaping of the conditions for regional development requires a continuous decision making ensuring an effective impact on the quality of the natural environment. A special role plays here the verification of the tasks that are being performed as to what degree the set objectives have been met. Therefore being capable of constantly monitoring current situation in individual units of the region, particularly in terms of the assessment of environmental conditions, plays an extremely important role. Developing suitable methods and having skills to interpret the data obtained on this basis constitute a starting point for defining opportunities and threats to the development of a given territorial system.

\section{THE RESEARCH METHODOLOGY AND THE COURSE OF THE RESEARCH PROCESS}

In the relevant literature, one of the most widespread form of examining the issues concerned with economic potential of regions are assessments published in the form of rankings, which are increasingly more frequently considered an independent area of analyses whose results are used to do comparisons at the international, regional as well as local level. The strength of the rankings lies in their ability to synthesize complex information with the results being ordered hierarchically for the entire set of units, thus facilitating the process of comparing and formulating general conclusions that are significant when shaping regional policy and necessary when analysing the degree of the socio-economic development of regions. 
The starting point for conducting the study is to determine the set of characteristics comprising the most complete and comprehensive description possible of the economic potential level of the individual counties. This issue is often reflected in the literature on the subject as a part of the disquisition on the measure of local development. In this field numerous authors present various concepts pertaining to the sets of characteristics, making it possible to define the level of development of a given local unit. For example, within the framework of the analyses of the environmental governance T. Borys distinguishes 17 areas to which specific indicators have been allocated (Borys 2005). The choice of variables was dictated by the literature on this subject and the availability of the data, because the study was carried out for the years 2006-2012. Referring to the current content of the body of literature addressing this issue as well as own work, the authors of this article created a list of characteristics that are fully consistent with the need to examine the quality of life at the level of the county self-government. Owing to limited access to information at the local level, for the detailed study a set of nine characteristics has been taken into account, as demonstrated in the table:

Table 1. The set and nature of the characteristics taken into account when assessing the economic potential of a county

\begin{tabular}{|c|l|l|}
\hline \hline Enumeration & \multicolumn{1}{|c|}{ Variable name } & \multicolumn{1}{|c|}{ Variable character } \\
\hline \hline X1 & $\begin{array}{l}\text { The share of households connected to a sewerage and water- } \\
\text {-supply network }\end{array}$ & stimulant \\
\hline X2 & Mixed waste collected in one year per capita (tons) & destimulant \\
\hline X3 & Publicly accessible green areas per 10 000 inhabitants (hectares) & stimulant \\
\hline X4 & Electricity consumption per capita ( MWh) & destimulant \\
\hline X5 & Gas consumption per capita (Mt) & destimulant \\
\hline X6 & Wooded land: forestation (\%) & stimulant \\
\hline X7 & Total sewage disposal per 1000 inhabitants & destimulant \\
\hline X8 & Particulate pollutants per county area & destimulant \\
\hline X9 & Gaseous pollutants per county area (tons/year) & destimulant \\
\hline \hline
\end{tabular}

S o u r c e : own study based.

Within the created set of characteristics, the information was included describing the environmental pollution, availability of green lands, and informa- 
tion on the status and threats to the environment. Considering that there are natural differences resulting from the area size and the number of inhabitants in the unit concerned, each characteristic is relative.

The starting point was the variation coefficients analysis of the variables tested. Critical value was set at $5 \%$. All variables were characterized by a coefficient of variation above the critical value.

For the purpose of comparing the environmental potential of voivodships, a linear ordering method has been used which is the method of standardised sums. It finds its application in the analysis of complex phenomena of which the diagnosis of environmental conditions certainly is, given the need to compare different objects, such as, in this case, voivodships. The methods of linear ordering allows for ranking the analysed objects from "the best" to "the worst", with the ranking criterion being the extent of the complex phenomenon. The selection of the variables used to describe the complex phenomenon is mostly of substantive nature, and while producing the synthetic measure describing the complex phenomenon, the degree of the variables correlation is of no importance.

The higher the value of the synthetic variable, the greater the extent of the complex phenomenon that is being tested. It is thus possible to order the objects by the extent of the complex phenomenon alone on the basis of the value of the standardized sums. The objective of producing the measure of development is to obtain values defined on the interval [0:1], whereby the closer the value $m_{i}$ is to 1 , the better it shows the extent of the complex phenomenon in the object concerned. The particular ranking thus obtained makes it possible to compare the situations of individual units, as well as allows for the analysis of the shifts in the trends occuring during the period in question.

An additional aim of the authors was to group the districts of the province of Lower Silesia into subsets due to environmental conditions. The grouping of objects can be done using cluster analysis. The purpose of cluster analysis is to create groups of objects as similar as possible to each other and at the same time the most different from the other groups of objects. The method of cluster analysis which is believed to be a very effective method is Ward's method (Parysek 1982). The Ward's method is one of the agglomerative hierarchical methods. The methods of the hierarchical agglomeration of objects with multiple characteristics which G.M. Lance and W.T. Williams proposed include several variants (Lance, Williams 1967). These variants have different ways of determining the distance matrix between the groups of objects in the multivariate 
classificatory space. The Ward's method provides a special case of the general pattern of objects clustering developed by G.M. Lance and W.T. Williams. The result of the analysis is a dendrogram, which is a graphic interpretation of the obtained results.

The Ward's method moves towards minimizing the error sum of squares of any pair of clusters which can be formed at any stage. The Ward's method is considered very effective aiming at producing small clusters (Grabiński, Sokołowski 1984, 63-79).

\section{THE OUTCOME OF THE RESEARCH AND CONCLUSIONS}

In the light of the theoretical disquisition introduced in the paper, the objective of the research results presented below is to demonstrate the extent of disparities in the environmental potential in the Lower Silesian Voivodship, in the county system. The study was conducted based on a few basic assumptions:

- research object - local self-government units of the Lower Silesian Voivodship,

- cross-section of the research - the county's level. The voivodship consists of 26 land counties and three cities with county rights Wrocław, Jelenia Góra and Legnica,

- the time horizon of the research spanned the years 2006-2012.

The results presenting the situation of the Lower Silesian counties in the environmental sphere between 2006-2012 are presented in Table 2 (the information is ordered according to the value of the development measure in 2012).

Table 2. Ranking of the Lower Silesian counties in terms of their environmental potential in years 2006-2012

\begin{tabular}{|l|c|c|c|c|c|c|c|}
\hline \hline & $\mathbf{2 0 0 6}$ & $\mathbf{2 0 0 7}$ & $\mathbf{2 0 0 8}$ & $\mathbf{2 0 0 9}$ & $\mathbf{2 0 1 0}$ & $\mathbf{2 0 1 1}$ & $\mathbf{2 0 1 2}$ \\
\hline \hline Powiat zgorzelecki & 0,37 & 0,38 & 0,36 & 0,34 & 0,38 & 0,39 & 0,39 \\
\hline Powiat m. Legnica & 0,45 & 0,45 & 0,43 & 0,42 & 0,44 & 0,43 & 0,42 \\
\hline Powiat m. Wrocław & 0,46 & 0,49 & 0,48 & 0,54 & 0,50 & 0,46 & 0,46 \\
\hline Powiat m.Jelenia Góra & 0,58 & 0,60 & 0,60 & 0,55 & 0,59 & 0,56 & 0,53 \\
\hline Powiat lubiński & 0,60 & 0,59 & 0,57 & 0,56 & 0,59 & 0,57 & 0,56 \\
\hline Powiat jeleniogórski & 0,58 & 0,61 & 0,55 & 0,51 & 0,56 & 0,57 & 0,56 \\
\hline Powiat wrocławski & 0,54 & 0,53 & 0,58 & 0,59 & 0,59 & 0,61 & 0,60 \\
\hline
\end{tabular}




\begin{tabular}{|c|c|c|c|c|c|c|c|}
\hline & 2006 & 2007 & 2008 & 2009 & 2010 & 2011 & 2012 \\
\hline Powiat wałbrzyski & 0,67 & 0,69 & 0,67 & 0,65 & 0,67 & 0,63 & 0,62 \\
\hline Powiat lubański & 0,65 & 0,66 & 0,64 & 0,61 & 0,65 & 0,64 & 0,63 \\
\hline Powiat świdnicki & 0,69 & 0,70 & 0,66 & 0,64 & 0,67 & 0,65 & 0,65 \\
\hline Powiat głogowski & 0,67 & 0,69 & 0,67 & 0,66 & 0,66 & 0,66 & 0,65 \\
\hline Powiat polkowicki & 0,68 & 0,70 & 0,67 & 0,65 & 0,67 & 0,67 & 0,65 \\
\hline Powiat dzierżoniowski & 0,64 & 0,66 & 0,66 & 0,64 & 0,67 & 0,66 & 0,65 \\
\hline Powiat jaworski & 0,66 & 0,68 & 0,66 & 0,62 & 0,65 & 0,66 & 0,66 \\
\hline Powiat Iwówecki & 0,65 & 0,67 & 0,62 & 0,62 & 0,66 & 0,67 & 0,66 \\
\hline Powiat kłodzki & 0,70 & 0,71 & 0,69 & 0,65 & 0,69 & 0,68 & 0,67 \\
\hline Powiat średzki & 0,72 & 0,73 & 0,69 & 0,66 & 0,69 & 0,69 & 0,68 \\
\hline Powiat legnicki & 0,71 & 0,72 & 0,70 & 0,67 & 0,70 & 0,69 & 0,69 \\
\hline Powiat wołowski & 0,65 & 0,64 & 0,63 & 0,66 & 0,71 & 0,71 & 0,69 \\
\hline Powiat trzebnicki & 0,71 & 0,71 & 0,68 & 0,66 & 0,70 & 0,70 & 0,70 \\
\hline Powiat złotoryjski & 0,71 & 0,71 & 0,69 & 0,66 & 0,70 & 0,70 & 0,70 \\
\hline Powiat oleśnicki & 0,73 & 0,72 & 0,73 & 0,68 & 0,73 & 0,71 & 0,71 \\
\hline Powiat oławski & 0,74 & 0,74 & 0,71 & 0,75 & 0,73 & 0,71 & 0,71 \\
\hline Powiat kamiennogórski & 0,71 & 0,73 & 0,70 & 0,67 & 0,72 & 0,72 & 0,71 \\
\hline Powiat ząbkowicki & 0,69 & 0,70 & 0,68 & 0,67 & 0,71 & 0,72 & 0,71 \\
\hline Powiat bolesławiecki & 0,75 & 0,78 & 0,75 & 0,74 & 0,78 & 0,77 & 0,76 \\
\hline Powiat strzeliński & 0,77 & 0,79 & 0,77 & 0,74 & 0,79 & 0,79 & 0,78 \\
\hline Powiat milicki & 0,80 & 0,82 & 0,81 & 0,77 & 0,81 & 0,80 & 0,80 \\
\hline Powiat górowski & 0,85 & 0,86 & 0,83 & 0,80 & 0,83 & 0,81 & 0,81 \\
\hline
\end{tabular}

S o u r c e : own study based.

The results of the presented ranking show a great similarity in terms of the ranking place of a given county in particular years. The comparison of the presented results reveals the predominance of land counties over urban counties. In this sphere, the leaders are górowski county and milicki county which at the same time usually fare the worst in the analysis concerned solely with the assessment of the economic potential. This observation is linked to a certain interdependency resulting from the fact that low economic activity trans- 
lates into relatively smaller consumption of gas, energy and reduced air pollution, which in turn translates into a better quality of life in these areas in the environmental sphere. It is also for these very reasons that the urban counties occupy the bottom places. In this regard zgorzelecki county remains a negative example with its place at the bottom of the ranking owing to the negative environmental impact of the Brown Coal Mine and Turów Power Plant located in the county.

For a detailed analysis of the situation in the environmental sphere it is necessary to analyze the results in relation to the individual characteristics. In this regard, there is no predominance of one county over the rest in any of the aspects that have been examined. Nevertheless, in the counties faring the worst in the environmental sphere one can notice the accumulation of the negative phenomena, which can be found in zgorzelecki county (lowest position in terms of waste, sewage disposal, air pollution) as well as the urban counties. For the majority of the examined characteristics, there is skewness to the left with the clustering of the counties, which is significantly above the average, around the unit that is best for the characteristic concerned. It is especially evident in terms of such characteristics as mixed waste collected in one year per capita (tones), electricity consumption per capita, total sewage disposal per 1000 inhabitants, particulate pollutants per county area and gaseous pollutants (tons/year) per county area. Publicly accessible green areas are the only characteristic from the set describing the environmental sphere where a significant predominance of one county over the rest occurs (the predominance of górowski county and strzeliński county).

From the perspective of the presented research results it is also important to pay attention to the degree of disparity in the value of the particular characteristics recorded in the successive years and assessed on the basis of the coefficients of variation.

Table 3. Coefficients of variation for the studied characteristics of the environmental potential in the years 2006-2012

\begin{tabular}{|c|c|c|c|c|c|c|c|c|c|}
\hline \hline Rok & $\mathbf{Z 1}$ & $\mathbf{Z 2}$ & $\mathbf{Z 3}$ & $\mathbf{Z 4}$ & $\mathbf{Z 5}$ & $\mathbf{Z 6}$ & $\mathbf{Z 7}$ & $\mathbf{Z 8}$ & $\mathbf{Z 9}$ \\
\hline \hline 2006 & $7,8 \%$ & $39,3 \%$ & $144,3 \%$ & $16,8 \%$ & $33,2 \%$ & $49,6 \%$ & $189,5 \%$ & $160,3 \%$ & $278,4 \%$ \\
\hline 2007 & $7,8 \%$ & $36,4 \%$ & $142,8 \%$ & $17,6 \%$ & $35,2 \%$ & $49,5 \%$ & $200,2 \%$ & $179,5 \%$ & $277,8 \%$ \\
\hline 2008 & $7,7 \%$ & $32,4 \%$ & $143,5 \%$ & $10,9 \%$ & $38,3 \%$ & $49,6 \%$ & $193,7 \%$ & $185,2 \%$ & $285,3 \%$ \\
\hline 2009 & $7,6 \%$ & $35,1 \%$ & $141,2 \%$ & $10,2 \%$ & $38,6 \%$ & $49,6 \%$ & $206,1 \%$ & $209,5 \%$ & $284,3 \%$ \\
\hline
\end{tabular}




\begin{tabular}{|c|c|c|c|c|c|c|c|c|c|}
\hline \hline Rok & $\mathbf{Z 1}$ & $\mathbf{Z 2}$ & $\mathbf{Z 3}$ & $\mathbf{Z 4}$ & $\mathbf{Z 5}$ & $\mathbf{Z 6}$ & $\mathbf{Z 7}$ & $\mathbf{Z 8}$ & $\mathbf{Z 9}$ \\
\hline \hline 2010 & $7,6 \%$ & $35,7 \%$ & $145,5 \%$ & $11,2 \%$ & $34,6 \%$ & $49,5 \%$ & $235,0 \%$ & $189,2 \%$ & $250,9 \%$ \\
\hline 2011 & $7,4 \%$ & $31,6 \%$ & $150,7 \%$ & $12,1 \%$ & $33,6 \%$ & $49,5 \%$ & $218,0 \%$ & $162,7 \%$ & $258,2 \%$ \\
\hline 2012 & $7,4 \%$ & $31,6 \%$ & $150,7 \%$ & $12,1 \%$ & $33,6 \%$ & $49,5 \%$ & $204,9 \%$ & $148,6 \%$ & $259,9 \%$ \\
\hline \hline
\end{tabular}

S o u r c e : own study based.

The characteristics which cause the greatest disparities in the situation of the Lower Silesian counties in the environmental sphere are in the first place gaseous pollutants, for which the coefficients of variation for this characteristic exceed $250 \%$ in the successive years. A significant role also play particulate pollutants per county area, total sewage disposal per 1000 inhabitants and publicly accessible green areas per 10000 inhabitants (hectares).

In accordance with the proposed research steps, the important point is the presentation of the results obtained from the cluster analysis of the Lower Silesian counties in the years 2006-2012 (Fig. 2).

Due to the limited space of this paper, the graphic presentation of the clusters has been limited to the year 2012. Nonetheless, the trends observed in this period also apply to the changes detected in the earlier years. The analysis of the counties of Lower Silesia suggests that there are three distinct clusters of counties in terms of their economic potential. In each of the year in question one of the clusters is made up of Zgorzelecki county and the city of Legnica. The second cluster comprises głogowski county and the city of Wrocław. These groups of counties, according to the applied Ward's method, show significant differences when compared with the situation of the remaining units which make up the third cluster. Considering the fact that the first two clusters encompassing Zgorzelecki county and the cities of Wrocław and Legnica, are, according to the ranking (Table 2), characterized by the worst situation in terms of the environmental conditions, then the similarities among them and a significant difference in comparison with the rest tend to expose them as problematic areas in terms of the quality of the environment in the voivodship of Lower Silesia. 
Figure 1. The application of Ward's method to assess the similarities in the distribution of environmental conditions in the Lower Silesian counties between 2010-2012

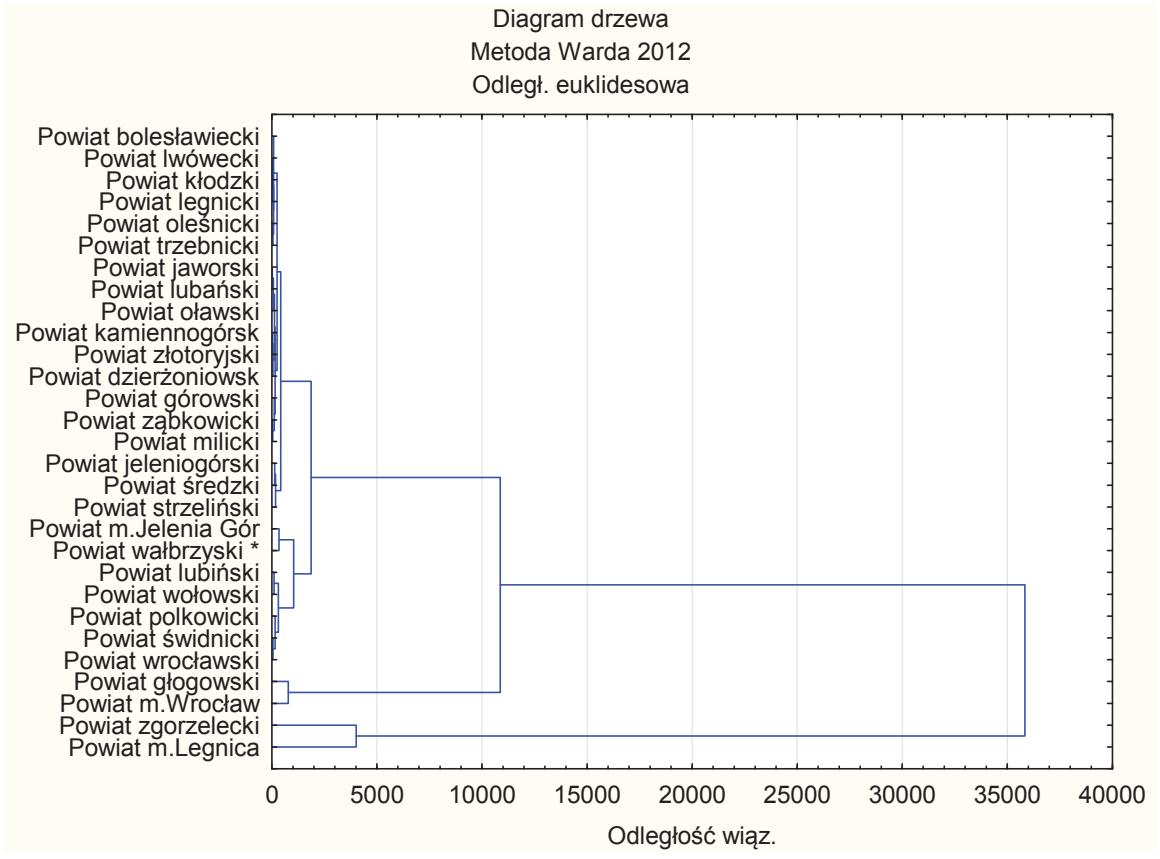

S o u r c e : own study based with a use of Statistica software.

The research on the changes in the environmental conditions of the counties of Lower Silesian Voivodship in the years 2006-2012 conducted by the application of the selected statistical methods leads to the following conclusions: first of all, the natural environment of the voivodship is to a great extent spatially diverse; there are areas of severely degraded land that are negatively distinct from other areas, most notably Zgorzelecki county and the cities of Wrocław and Legnica. The economic activity located there has a significant impact on this situation, which further translates into air pollution in big urban and industrial agglomerations as well as the level of waste produced by the industry, municipal services and trade. The research results show that the disparities between the best and the worst counties are becoming more deeply embedded in terms of their environmental potential, which is further confirmed by the lack of considerable changes over time, as revealed by the ranking developed with the application of the method of standardized sums. 
Within the scope of the research on environmental conditions certain objective difficulties of methodological nature contribute to an obvious barrier when formulating conclusions on the basis of the applied statistical methods. The research the authors conducted allows for taking account of several significant limiting factors when producing rankings and properly assessing the obtained information. This is related to the kind and status of the data taken into account in the research (majority of the data is secondary, obtained from the public statistics sources) as well as to the restrictions with regard to acquiring comparable and complete information, which further results in having to reject the indicators important for monitoring the environmental conditions because of a lack of available data.

\section{REFERENCES}

Borys T. (2005), Wskaźniki zrównoważonego rozwoju, Wyd. Ekonomia i Środowisko, Warszawa -Białystok.

Fiedor B., Czaja S., Graczyk A., Jakubczyk S. (2002), Podstawy ekonomii środowiska i zasobów naturalnych, Wydawnictwo C. H. Beck, Warszawa.

Fujita M., Krugman P., Venables A. J. (2001). The Spatial Economy: Cities, Regions, and International Trade by Journal of Economics, vol. 73, no. 1.

Grabiński T., Sokołowski A. (1984), Z badań nad efektywnością wybranych procedur taksonomicznych, ZN AE, no. 181/1984, Kraków, 63-79.

Lance G. M., Williams W. T., (1967). A General Theory of Classificatory Sorting Strategies I. Hierarchical System. Computer Journal, no 9.

Parysek J. J. (1982), Metody klasyfikacji w geografii, Seria Geografia, nr 31, Uniwersy tet Adama Mickiewicza, Poznań.

Stackelberg K., Hahne U. (1998), Teorie rozwoju regionalnego, [w:] Rozwój ekonomiczny regionów. Rynek pracy. Procesy Migracyjne. Polska, Czechy, Niemcy, Raport IPiSS, S. Golinowska (red.), Zeszyt nr 16, Warszawa, 30.

Szewczuk A., Kogut M., Zioło M. (2011), Rozwój lokalny i regionalny. Teoria i praktyka, Wydawnictwo C. H. Beck, 18. 